\title{
Insulin resistance and adaptation of pancreatic beta cells during pregnancy
}

\begin{abstract}
Insulin resistance is described as reduced sensitivity of the body tissues to insulin. In pregnant women insulin resistance increases during each trimester of pregnancy due to the hormones produced by the placenta and many other factors which are not yet fully recognised. Growing insulin resistance leads to an increase in beta cell mass and number and insulin secretion, which helps to maintain glucose homeostasis and normal foetal development. However, in cases of severe insulin resistance, insufficient compensation of pancreatic beta cells or reduced pancreatic beta-cell function, glycaemic levels are increased and gestational diabetes mellitus develops.
\end{abstract}

The aim of the present review is to analyse the factors affecting insulin resistance and the adaptation of pancreatic beta cells during pregnancy and methods of insulin resistance assessment. (Clin Diabetol 2018; 7, 5: 222-229)

Key words: insulin resistance, pregnancy, adipokines, gestational diabetes mellitus, adaptation of pancreatic beta cells in pregnancy

\section{Introduction}

Insulin resistance is described as reduced sensitivity of the body tissues to insulin - primarily muscle, adipose tissue and the liver, which consequently leads

Address for correspondence:

lek. Anna Zielińska

Klinika Endokrynologii, Diabetologii i Chorób Wewnętrznych

Uniwersytet Medyczny w Białymstoku

ul. Marii Curie-Skłodowskiej 24A, 15-276 Białystok

Phone: +48 858318 239, fax: +48 857447611

e-mail: z.aneczka@buziaczek.pl

Clinical Diabetology 2018, 7, 5, 222-229

DOI: $10.5603 /$ DK.2018.0022

Received: 28.08 .2018

Accepted: 11.09.2018 to disturbances in the metabolism of carbohydrates, lipids and proteins. Moreover, increased insulin levels in insulin-resistant patients have a mitogenic effect. The disturbance occurs in patients with obesity, type 2 diabetes, hypertension, polycystic ovary syndrome (PCOS) and gestational diabetes mellitus (GDM). In healthy pregnant women a gradual increase in insulin resistance occurs due to the hormones produced by the placenta: human placental lactogen (hPL), estrogen, progestagen, human chorionic gonadotropin (hCG), growth hormone $(\mathrm{GH})$, prolactin (PRL) and cortisol [1, 2]. The placenta also produces significant amounts of cytokines, which are also produced by adipose tissue, i.e. adipokines, such as leptin and $\mathrm{TNF} \alpha$ [3]. This results in numerous metabolic changes that facilitate the provision of nutrients to the developing foetus.

Due to growing insulin resistance, an increase in the mass and amount of beta-cells and an increase of insulin secretion occure. Thanks to this the normal level of glucose, i.e. the primary energy substrate, is maintained, which is crucial for healthy foetal development. The transport of glucose across the placenta occurs by facilitated diffusion along a concentration gradient, thus the amount of glucose delivered to the fetus depends on its concentration in the mother's blood serum.

During the third trimester of pregnancy in healthy women, the degree of insulin resistance is comparable to that in patients with type 2 diabetes. During pregnancy, insulin sensitivity decreases by about $50-60 \%$ [4]. In cases of excessively increased insulin resistance, insufficient compensation of pancreatic beta cells (insufficient increase in insulin secretion) or decreased function of pancreatic beta cells, glycaemia increases and GDM develops [5].

A number of animals studies have been conducted which confirm the increase in the number and size of beta cells during pregnancy. However, there are very few studies assessing the function of beta cells and fac- 
tors affecting compensatory mechanisms in pregnant women. In our review work, we will focus on methods for assessing insulin resistance, factors affecting insulin resistance in pregnancy, and the adaptation of pancreatic beta cells during pregnancy.

\section{Methods for assessing insulin resistance and insulin sensitivity}

The gold standard for the assessment of insulin resistance is the hyperinsulinemic-euglycemic clamp technique, which is difficult to implement in pregnant women due to ethical issues [6]. The easiest and most frequently used insulin resistance index is the HOMA-IR index (Homeostatic Model Assessment for Insulin Resistance) calculated using the following formula: HOMA-IR = (fasting glucose concentration $[\mathrm{mg} / \mathrm{dL}] \times$ fasting insulin concentration [mIU/l]) divided by 405 [7]. A more adequate study with proven very good correlation with the hyperinsulinemic-euglycemic clamp is the calculation of the Matsuda insulin sensitivity index $\left(\mathrm{IS}_{\mathrm{OGTT}}\right)$ based on results obtained during a $75 \mathrm{~g}$ oral glucose tolerance test (OGTT) [8]. It is calculated using the following formula: $\mathrm{IS}_{\mathrm{OGTT}}=10,000 / \sqrt{ }[(\mathrm{FPG} \times \mathrm{FPI})$ $\times(G \times I)$ ], where FPG $=$ fasting plasma glucose, FPI = fasting plasma insulin, $\mathrm{G}=$ mean glucose during OGTT and I - mean insulin during OGTT [9]. The latest insulin sensitivity index proposed by Wagner et al. is the index of non-esterified fatty acids (NEFA-index), which includes body mass index (BMI), insulin levels during OGTT (0 min, $60 \mathrm{~min}$ and $120 \mathrm{~min}$ ) and NEFA during OGTT (0 $\mathrm{min}$ and $120 \mathrm{~min}$ ) [10]. The authors of that study emphasise that the concentration of NEFA is closely related to insulin sensitivity. The index was calculated based on a comparison of the hyperinsulinemiceuglycemic clamp and OGTT with the use of insulin and NEFA concentrations in healthy non-pregnant subjects. It was calculated to be more useful in pregnant women to show increased insulin resistance than other previously used indices, e.g. the Matsuda index.

\section{Factors affecting insulin resistance in pregnancy}

The results of many studies confirmed that insulin resistance during pregnancy is related to BMI and, consequently, to the amount of adipose tissue before pregnancy and weight gain during pregnancy [11-13]. There is also evidence that insulin sensitivity depends on the levels of physical activity before and during pregnancy [13]. According to Marilyn Lacroix, glucose metabolism disorder during pregnancy indicates an existing pathology related to insulin resistance or insulin secretion, which in the future may lead to the development of diabetes. Therefore, pregnancy is a 'window' to identifying women with an increased risk of developing diabetes type 2 in the future [2]. In overweight pregnant women, the development of diabetes is associated with insulin resistance which was already increased prior to pregnancy, while the hormones and cytokines secreted by the placenta increased it even further, hence contributing to the development of GDM. However, in addition to increasing insulin resistance, lean women who develop GDM also seem to have insulin secretory defects [14].

Insulin resistance and pancreatic beta cell dysfunction are the two major metabolic disturbances involved in the pathogenesis of GDM. Previous clinical and experimental studies indicated that adipose tissue dysfunction leads to disturbed production of cytokines, which are important factors in the development of GDM. Thus far, the importance of several hormones produced by adipose tissue has been well documented. The functions of leptin, adiponectin, resistin and proinflammatory cytokines (tumour necrosis factor-alpha - TNF-alpha, interleukin- 6 and C-reactive protein) have been particularly recognised.

Leptin regulates the amount of body fat and body weight by inhibiting the secretion of neuropeptide $Y$ in the hypothalamus, as well as in adipose tissue, the liver and other organs [15]. It is produced primarily in adipose tissue, but also in the placenta $[5,16]$. Its concentration increases with the amount of adipose tissue, weight gain and hyperinsulinaemia [17]. It inhibits the secretion of insulin from pancreatic beta cells. During pregnancy, leptin levels increase in the first and second trimesters, reaching their peak at week 28 , and they are 2-3 times higher than in non-pregnant women. In the third trimester, leptin concentrations stabilise [17, 18]. Although there are different opinions about the role of leptin in the development of GDM, most study results confirm that hyperleptinaemia during the first trimester of pregnancy is a predictor of $\operatorname{GDM}[5,17,19]$.

The role of adiponectin is also well recognised. Its concentrations are inversely proportional to the amount of adipose tissue, BMI and insulin resistance $[16,20]$. It is produced predominantly in adipocytes, but also in the syncytiotrophoblast of the placenta $[5,16]$. It increases the sensitivity of the body tissues to insulin. In normal pregnancy, the concentrations of adiponectin decrease during each trimester [4, 21, 22]. Numerous studies demonstrated that adiponectin concentrations in women with GDM are lower compared to the control group [20, 23-25]. It was also shown that its low concentrations during the first weeks of pregnancy are a clinical predictor for GDM development [19, 20, 26, 27].

The concentrations of resistin in normal pregnancy increase during the third trimester. It seems that resistin 
affects carbohydrate metabolism and the development of insulin resistance. It is associated with the amount of adipose tissue and its increased concentration during pregnancy is probably related to body weight gain [17]. However, the role of resistin in insulin resistance and in the development of GDM is unclear and researchers hold divergent opinions on this issue [24, 28-34].

TNF-alpha is a pro-inflammatory cytokine which reduces insulin sensitivity and inhibits insulin secretion from pancreatic beta cells. A positive correlation was found with the amount of adipose tissue and a decrease in TNF-alpha concentration after slimming and weight loss [5]. TNF-alpha is produced by the placenta and is a potential mediator of insulin resistance during pregnancy [3]. Studies on pregnant women indicated that the concentrations of this cytokine increase during the second and third trimesters in patients with GDM. In the majority of studies higher TNF-alpha concentrations were found in patients with GDM compared to the control group [35-37]. In addition, positive correlations with $\mathrm{BMI}$ and insulin resistance and negative correlations with insulin sensitivity were discovered $[3,5]$.

Studies are still carried out regarding many other, not yet fully recognised cytokines and adipokines which may be involved in the development of GDM and whose concentrations change during pregnancy, e.g. betatrophin, omentin-1, chemerin, fetuin-A, fetuin-B, fibroblast growth factors 19 and 21 (FGF19 and FGF21), fibroblast growth factor 21 (FBF21), fatty acid binding proteins - fatty acid-binding protein 4 (FABP4) and retinol binding proteins - retinol-binding protein 4 (RBP4).

Betatrophin is a recently discovered hormone which is produced in the liver and adipose tissue [38]. It takes part in the metabolism of lipids and is associated with insulin resistance $[39,40]$. Its concentration is elevated in type 2 diabetes, obesity and gestational diabetes mellitus [41-46]. In our first prospective study of healthy pregnant and postpartum women, we demonstrated that despite increasing insulin resistance and increasing triglyceride concentrations, the concentrations of betatrophin significantly decrease in women during pregnancy and increase 3 months after delivery, reaching identical concentration levels as in the control group of healthy non-pregnant women [47].

Fatty acid-binding protein 4 (FABP4) is an important carrier of intracellular fatty acids [48]. Its role in the development of metabolic disorders, type 2 diabetes and insulin resistance during pregnancy and GDM is of interest to many scientists. FABP4 seems to be important in maintaining glucose homeostasis, as its increased concentrations result in reduced uptake and utilisation of glucose by muscle and liver cells [49].
One study showed that higher FABP4 concentrations are associated with higher insulin resistance in patients with GDM, which may be one of the pathomechanisms responsible for GDM development [48]. Subsequent studies of larger patient groups confirmed that FABP4 is associated with insulin resistance during pregnancy and its higher concentrations in the first trimester are associated with an increased risk of developing GDM and may be early clinical markers of GDM [49-51].

Other important cytokines in the pathogenesis of GDM are fibroblast growth factors 19 and 21 (FGF19 and FGF21). FGF19 is mainly secreted in the small intestine and has insulin-like effect [52]. FGF21 is secreted by adipose tissue, the pancreas and the liver and it has a glucagon-like effect. However, both molecules stimulate the uptake of glucose by adipocytes and are thus associated with improved glucose tolerance $[52,53]$. Observation of concentration levels of these adipokines in pregnant women during the second trimester revealed decreased FGF19 concentrations and increased FGF21 concentrations in patients with gestational diabetes mellitus [52]. During the third trimester of pregnancy, serum FGF21 levels did not differ significantly in women with GDM compared to healthy ones, while being significantly higher in the placenta of women with GDM [54]. Both adipokines are strongly associated with insulin resistance $[52,53]$. Low concentrations of FGF19 are probably important in the development of GDM, while elevated FGF21 levels may be the mechanism that compensates that disorder. Megia et al. showed in their work that there is a significant correlation between the levels of FGF21 in umbilical cord blood and the BMI of the newborn and that its concentrations in the mother's serum are similar to those observed in umbilical cord blood [55]. In another study, the concentrations of FGF21 in the serum of pregnant women were significantly correlated with fasting insulin, triglycerides and HOMA-IR concentrations, but no higher concentrations of the cytokine in GDM patients were found [53].

Retinol-binding protein (RBP4) is secreted in the liver and adipose tissue. It affects hepatic gluconeogenesis and, due to phosphoenolpyruvate carboxykinase (PEPCK), decreases the effects of insulin in muscles. Thus, it increases insulin resistance and is involved in the pathogenesis of type 2 diabetes [56, 57]. The adipokine is also being studied as a marker of insulin resistance and development of GDM, although research results on its effect on pregnant women are contradictory [58-64]. Hu S et al. in their meta-analysis involving over 1.200 patients, similarly to Huang QT et al. in their meta-analysis, found out that RBP4 is associated with GDM $[65,66]$. Hence, more in-depth studies of its 
concentration levels during each trimester of pregnancy and postpartum are needed.

Omentin-1 is also an adipokine produced in adipose tissue and the placenta and it has a beneficial effect on insulin sensitivity. Its concentrations are lower in people with insulin resistance, i.e. those suffering from obesity, type 2 diabetes, PCOS, and GDM [67-69]. The highest adipokine concentrations in pregnant women were observed during the first trimester and they decreased during the second trimester [70]. Barker et al. showed that omentin-1 levels in obese women are higher in the placenta than in adipose tissue [71]. The authors of the study also demonstrated that the concentrations are significantly lower in non-obese women with GDM compared to non-obese pregnant women with normal glucose tolerance. However, no difference was indicated in obese women with GDM and normal glucose tolerance [71]. It was shown that omentin- 1 concentrations lower than $38 \mathrm{ng} / \mathrm{ml}$ are associated with a 4-fold greater risk of developing GDM [67]. In a prospective study of pregnant women during the second and third trimesters, no significant differences in omentin-1 levels in the plasma of healthy women and those with GDM were identified. However, significantly lower concentrations of omentin-1 in umbilical cord blood of newborns and mothers with GDM were observed [72]. Although only a few reports on the concentrations of omentin-1 in pregnant women are available, the majority of them confirm that the lower concentrations are observed in GDM patients, which is probably associated with insulin resistance during pregnancy.

Chemerin is an adipokine produced by various tissues, particularly adipose tissue [73]. It is also secreted by the placenta [74]. A study based on a very small sample ( 9 women with GDM and 8 healthy pregnant women) demonstrated that the concentrations of chemerin during the third trimester of pregnancy and 3 months after delivery significantly differ in both groups. They are significantly lower and remain unchanged after delivery in women with GDM, while significantly decreasing after delivery in healthy women [75]. Although subsequent studies did not confirm this observation, they showed statistically significantly higher concentrations of chemerin in patients with GDM compared to healthy women [76-78]. Nevertheless, in a study conducted by Pfau D. et al. no such differences were found [79]. In a study based on the largest patient sample (208 patients with GDM and 300 control patients), significantly higher concentrations (7-fold) of chemerin in patients with GDM and a strong correlation with HOMA-IR, fasting glucose and baby neonatal birth weight were observed [80]. Several studies also revealed positive correlations of chemerin with HOMA-IR $[77,79]$. The concentrations of chemerin increase during pregnancy in both healthy and GDM patients [78]. During the third trimester of pregnancy chemerin levels are significantly higher in patients with GDM in peripheral blood, umbilical cord blood, adipose tissue and the placenta $[79,81]$. Fluctuations in its concentrations during pregnancy and significant correlations with the insulin resistance index may suggest its important role in the development of GDM.

Very few studies showed that fetuin-A and fetuin-B levels in pregnant women with GDM are higher than those in pregnant women with no carbohydrate disorders. The levels of fetuin-A and fetuin-B decrease considerably after delivery $[82,83]$. Significant correlations between fetuin- $\mathrm{A}$ and $\mathrm{HbA}_{1 \mathrm{c}}$ concentrations, levels of cholesterol and triglycerides were found [82]. Moreover, fetuin-B significantly correlates with HOMA-IR, fasting insulin, and free fatty acids [83]. The adipokines may also play an important role in potentiating insulin resistance and in the development of metabolic changes in GDM $[82,83]$.

Another important factor affecting insulin resistance are thyroid hormones, which are primarily responsible for the regulation of energy balance and metabolism. It was suggested that they may influence the development of insulin resistance during pregnancy [84]. Low fT4 levels during early pregnancy are associated with an increased risk of GDM [85]. It was also shown that women with GDM are at a higher risk of developing thyroid disease and post-partum thyroiditis [86].

To sum up, adipokines and thyroid hormones seem to be important factors in the pathophysiology of insulin resistance and development of GDM. Due to the fact that there are very few studies on some cytokines and thyroid hormones during pregnancy, often based on small samples of women, further research in this area is needed.

\section{Adaptation of pancreatic beta cells to increasing insulin resistance during pregnancy}

From the first trimester of pregnancy, the number of pancreatic beta cells and their function increase, as there is a growing need for insulin in the subsequent stages of pregnancy [87]. In mice, a two- to five-fold increase in pancreatic beta cell mass during pregnancy occurs [88-90]. Van Assche et al. observed in their study of 5 women that pancreatic beta cell area increased 2.4 times during pregnancy compared to non-pregnant women [91]. Butler et al. compared pancreatic beta cell morphology in a larger group, i.e. 18 patients 
who died during pregnancy, 6 who died after delivery and 20 who were non-pregnant. They showed that pancreatic beta cell area increases during pregnancy 1.4 times with no change in beta cell size compared to non-pregnant women [92]. Pregnant patients had more pancreatic beta cells of smaller size and more new islets with new pancreatic beta cells. In the exocrine part of the pancreas, insulin-producing single cells were more common in pregnant and postpartum women than in non-pregnant women [92]. Differences in the size and amount of beta cells in mice and women may be due to the duration of pregnancy (3 weeks vs. 9 months) [90]. Placental lactogen is the key factor in beta-cell proliferation during pregnancy in mice and, due to prolactin receptor (PRLR) in pancreatic beta cells, causes elevated expression of the serotonin HTR2B receptor [89, 93-95]. Beta cells return to pre-pregnancy levels immediately prior to delivery and during the postnatal period, when the concentrations of placental lactogen decrease and prolactin levels increase, as prolactin increases HTR1D expression and decreases HTR2B expression. Serotonin, as a neurotransmitter and paracrine-acting hormone, is produced by pancreatic beta cells during pregnancy in mice and due to its ability to affect the function of the above-described receptors it participates in the regulation of beta-cell proliferation. This action was confirmed by treatment with serotonin in-vitro, which induced proliferation of pancreatic beta cells [95]. The serotonin produced by pancreatic beta cells of pregnant mice also increases insulin secretion after meals by activating the HTR3A receptor [96]. Blockade of this receptor has an effect on insulin secretion and glycaemia levels only in pregnant mice and no effect on non-pregnant mice is observed [96]. Another mechanism regulating the proliferation of beta cells in mice is the autonomic nervous system, whose activity is influenced by the central regulation of food intake and metabolism [97].

Unfortunately, not many studies have focused on humans and the exact mechanisms that are responsible for increasing the amount of beta cells in people are unknown. In an in-vitro cell culture study of human pancreatic beta cells, it was shown that the administration of prolactin, placental lactogen and growth hormone results in increased insulin secretion [98]. Beta cells in humans have a different proliferative potential and new beta cells are probably formed from stem cells. Unlike in mice, they are not generated from the proliferation of existing beta cells [92]. The mechanisms responsible for the proliferation of beta cells in humans are not well understood, and pregnancy is an additional factor that makes it difficult to conduct tests due to ethical issues. Hence, further cell culture research is needed, which may give us a better understanding of the factors affecting beta cell proliferation in humans.

\section{Conclusions}

Bearing in mind the fact that obesity and diabetes, including both GDM and type 2 diabetes, have reached epidemic proportions in the modern world, there has been an even greater need to expand our knowledge about insulin resistance. This is necessary in order to bring us closer to finding new therapeutic solutions that will help to reduce the complications that are linked to insulin resistance. We know that obesity is associated with adipokine production disorders and that obese women are more likely to develop GDM, which adversely affects foetal development and increases the risk of developing type 2 diabetes in both the mother and her child. Therefore, research into the pathogenesis of GDM and looking for new factors that have a predictive value and would allow screening for women at risk who should receive specialist care prior to conception to avoid the development of GDM are important. Adipokines are considered to be such potential factors and those that have been most thoroughly examined include: leptin, adiponectin, resistin and proinflammatory cytokines, all of which are described in the present article. However, initial reports on the role of other factors, including betatrofine, omentine-1, chemerin, fetuin, FGF19, FGF21, FABP4 and RBP-4, are equally interesting. Further prospective studies are needed on larger samples of women in order to determine their importance in the development of insulin resistance, not only during pregnancy, but also in general population.

\section{Acknowledgements}

AZM is a recipient of the Polish Diabetes Association Scientific Grant 2015.

\section{Conflict of interest}

The authors declare no conflict of interest.

\section{REFERENCES}

1. Ryan EA, Enns L. Role of gestational hormones in the induction of insulin resistance. J Clin Endocrinol Metab. 1988; 67(2): 341-347, doi: 10.1210/jcem-67-2-341, indexed in Pubmed: 3292560.

2. Lacroix M, Kina E, Hivert MF. Maternal/fetal determinants of insulin resistance in women during pregnancy and in offspring over life. Curr Diab Rep. 2013; 13(2): 238-244, doi: 10.1007/s11892-0120360-x, indexed in Pubmed: 23307191.

3. Kirwan JP, Hauguel-De Mouzon S, Lepercq J, et al. TNF-alpha is a predictor of insulin resistance in human pregnancy. Diabetes. 2002; 51(7): 2207-2213, doi: 10.2337/diabetes.51.7.2207, indexed in Pubmed: 12086951.

4. Catalano PM, Hoegh M, Minium J, et al. Adiponectin in human pregnancy: implications for regulation of glucose and lipid me- 
tabolism. Diabetologia. 2006; 49(7): 1677-1685, doi: 10.1007/ /s00125-006-0264-x, indexed in Pubmed: 16752186.

5. Fasshauer M, Blüher M, Stumvoll M. Adipokines in gestational diabetes. Lancet Diabetes Endocrinol 2014; 2: 488-499, doi:10.1016/ /S2213-8587(13)70176-1.

6. Bergman RN, Finegood DT, Ader M. Assessment of insulin sensitivity in vivo. Endocr Rev. 1985; 6(1): 45-86, doi: 10.1210/ /edrv-6-1-45, indexed in Pubmed: 3884329.

7. Matthews DR, Hosker JP, Rudenski AS, et al. Homeostasis model assessment: insulin resistance and beta-cell function from fasting plasma glucose and insulin concentrations in man. Diabetologia. 1985; 28(7): 412-419, doi: 10.1007/bf00280883, indexed in Pubmed: 3899825.

8. Kirwan JP, Huston-Presley L, Kalhan SC, et al. Clinically useful estimates of insulin sensitivity during pregnancy: validation studies in women with normal glucose tolerance and gestational diabetes mellitus. Diabetes Care. 2001; 24(9): 1602-1607, doi: 10.2337/ /diacare.24.9.1602, indexed in Pubmed: 11522706.

9. Matsuda M, DeFronzo RA. Insulin sensitivity indices obtained from oral glucose tolerance testing: comparison with the euglycemic insulin clamp. Diabetes Care. 1999; 22(9): 1462-1470, doi: 10.2337/diacare.22.9.1462, indexed in Pubmed: 10480510.

10. Wagner R, Fritsche $L$, Heni $M$, et al. A novel insulin sensitivity index particularly suitable to measure insulin sensitivity during gestation. Acta Diabetol. 2016; 53(6): 1037-1044, doi: 10.1007/ /s00592-016-0930-5, indexed in Pubmed: 27771766.

11. Catalano PM, Roman-Drago NM, Amini SB, et al. Longitudinal changes in body composition and energy balance in lean women with normal and abnormal glucose tolerance during pregnancy. Am J Obstet Gynecol. 1998; 179(1): 156-165, doi: 10.1016/s00029378(98)70267-4, indexed in Pubmed: 9704782.

12. Mclntyre HD, Chang AM, Callaway LK, et al. Hyperglycemia and Adverse Pregnancy Outcome (HAPO) Study Cooperative Research Group. Hormonal and metabolic factors associated with variations in insulin sensitivity in human pregnancy. Diabetes Care. 2010; 33(2): 356-360, doi: 10.2337/dc09-1196, indexed in Pubmed: 19880583.

13. Retnakaran R, Qi Y, Sermer M, et al. Pre-gravid physical activity and reduced risk of glucose intolerance in pregnancy: the role of insulin sensitivity. Clin Endocrinol (Oxf). 2009; 70(4): 615-622, doi: 10.1111/j.1365-2265.2008.03393.x, indexed in Pubmed: 18793347.

14. Catalano PM. Carbohydrate metabolism and gestational diabetes. Clin Obstet Gynecol 1994; 37: 25-38.

15. Triantafyllou GA, Paschou SA, Mantzoros CS. Leptin and Hormones: Energy Homeostasis. Endocrinol Metab Clin North Am. 2016; 45(3): 633-645, doi: 10.1016/j.ecl.2016.04.012, indexed in Pubmed: 27519135.

16. Powe CE. Early Pregnancy Biochemical Predictors of Gestational Diabetes Mellitus. Curr Diab Rep. 2017; 17(2): 12, doi: 10.1007/ /s11892-017-0834-y, indexed in Pubmed: 28229385.

17. Brink HS, van der Lely AJ, van der Linden J. The potential role of biomarkers in predicting gestational diabetes. Endocr Connect. 2016; 5(5): R26-R34, doi: 10.1530/EC-16-0033, indexed in Pubmed: 27492245

18. Briana DD, Malamitsi-Puchner A. Reviews: adipocytokines in normal and complicated pregnancies. Reprod Sci. 2009; 16(10): 921-937, doi: 10.1177/1933719109336614, indexed in Pubmed: 19474287.

19. Wójcik M, Chmielewska-Kassassir M, Grzywnowicz K, et al. The relationship between adipose tissue-derived hormones and gestational diabetes mellitus (GDM). Endokrynol Pol. 2014; 65(2): 134-142, doi: 10.5603/EP.2014.0019, indexed in Pubmed: 24802737.

20. Lacroix M, Battista MC, Doyon M, et al. Lower adiponectin levels at first trimester of pregnancy are associated with increased insulin resistance and higher risk of developing gestational diabetes mellitus. Diabetes Care. 2013; 36(6): 1577-1583, doi: 10.2337/ /dc12-1731, indexed in Pubmed: 23300287.
21. Paradisi G, lanniello F, Tomei $C$, et al. Longitudinal changes of adiponectin, carbohydrate and lipid metabolism in pregnant women at high risk for gestational diabetes. Gynecol Endocrinol. 2010; 26(7): 539-545, doi: 10.3109/09513591003632084, indexed in Pubmed: 20170346.

22. Fuglsang J, Skjaerbaek C, Frystyk J, et al. A longitudinal study of serum adiponectin during normal pregnancy. BJOG. 2006; 113(1): 110-113, doi: 10.1111/j.1471-0528.2005.00792.x, indexed in Pubmed: 16398779.

23. Ferreira AF, Rezende JC, Vaikousi $E$, et al. Maternal serum visfatin at 11-13 weeks of gestation in gestational diabetes mellitus. Clin Chem. 2011; 57(4): 609-613, doi: 10.1373/ /clinchem.2010.159806, indexed in Pubmed: 21325104.

24. Lain KY, Daftary AR, Ness RB, et al. First trimester adipocytokine concentrations and risk of developing gestational diabetes later in pregnancy. Clin Endocrinol (Oxf). 2008; 69(3): 407-411, doi: 10.1111/j.1365-2265.2008.03198.x, indexed in Pubmed: 18284645.

25. Williams MA, Qiu C, Muy-Rivera M, et al. Plasma adiponectin concentrations in early pregnancy and subsequent risk of gestational diabetes mellitus. J Clin Endocrinol Metab. 2004; 89(5): 2306-2311, doi: 10.1210/jc.2003-031201, indexed in Pubmed: 15126557.

26. Iliodromiti S, Sassarini J, Kelsey TW, et al. Accuracy of circulating adiponectin for predicting gestational diabetes: a systematic review and meta-analysis. Diabetologia. 2016; 59(4): 692-699, doi: 10.1007/s00125-015-3855-6, indexed in Pubmed: 26768001.

27. Thagaard IN, Krebs L, Holm JC, et al. Adiponectin and leptin as first trimester markers for gestational diabetes mellitus: a cohort study. Clin Chem Lab Med. 2017; 55(11): 1805-1812, doi: 10.1515/ /cclm-2017-0427, indexed in Pubmed: 28763297.

28. Cortelazzi D, Corbetta S, Ronzoni S, et al. Maternal and foetal resistin and adiponectin concentrations in normal and complicated pregnancies. Clin Endocrinol (Oxf). 2007; 66(3): 447-453, doi: 10.1111/j.1365-2265.2007.02761.x, indexed in Pubmed: 17302882 .

29. Kuzmicki M, Telejko B, Szamatowicz J, et al. High resistin and interleukin- 6 levels are associated with gestational diabetes mellitus. Gynecol Endocrinol. 2009; 25(4): 258-263, doi: 10.1080/09513590802653825, indexed in Pubmed: 19408175.

30. Georgiou HM, Lappas M, Georgiou GM, et al. Screening for biomarkers predictive of gestational diabetes mellitus. Acta Diabetol. 2008; 45(3): 157-165, doi: 10.1007/s00592-008-0037-8, indexed in Pubmed: 18496643.

31. Palik E, Baranyi E, Melczer Z, et al. Elevated serum acylated (biologically active) ghrelin and resistin levels associate with pregnancy-induced weight gain and insulin resistance. Diabetes Res Clin Pract. 2007; 76(3): 351-357, doi: 10.1016/j.diabres.2006.09.005, indexed in Pubmed: 17010469.

32. Lowe LP, Metzger BE, Lowe WL, et al. HAPO Study Cooperative Research Group. Inflammatory mediators and glucose in pregnancy: results from a subset of the Hyperglycemia and Adverse Pregnancy Outcome (HAPO) Study. J Clin Endocrinol Metab. 2010; 95(12): 5427-5434, doi: 10.1210/jc.2010-1662, indexed in Pubmed: 20843942.

33. Megia A, Vendrell J, Gutierrez C, et al. Insulin sensitivity and resistin levels in gestational diabetes mellitus and after parturition. Eur J Endocrinol. 2008; 158(2): 173-178, doi: 10.1530/EJE-07-0671, indexed in Pubmed: 18230823.

34. Lobo TF, Torloni MR, Gueuvoghlanian-Silva BY, et al. Resistin concentration and gestational diabetes: a systematic review of the literature. J Reprod Immunol. 2013; 97(1): 120-127, doi: 10.1016/j.jri.2012.10.004, indexed in Pubmed: 23432878.

35. Gao Xl, Yang Hx, Zhao Yi. Variations of tumor necrosis factoralpha, leptin and adiponectin in mid-trimester of gestational diabetes mellitus. Chin Med J (Engl). 2008; 121(8): 701-705, indexed in Pubmed: 18701022.

36. López-Tinoco $C$, Roca M, Fernández-Deudero A, et al. Cytokine profile, metabolic syndrome and cardiovascular disease risk in 
women with late-onset gestational diabetes mellitus. Cytokine. 2012; 58(1): 14-19, doi: 10.1016/j.cyto.2011.12.004, indexed in Pubmed: 22200508.

37. Atègbo JM, Grissa O, Yessoufou A, et al. Modulation of adipokines and cytokines in gestational diabetes and macrosomia. J Clin Endocrinol Metab. 2006; 91(10): 4137-4143, doi: 10.1210/ /jc.2006-0980, indexed in Pubmed: 16849405.

38. Zhang R, Abou-Samra AB. A dual role of lipasin (betatrophin) in lipid metabolism and glucose homeostasis: consensus and controversy. Cardiovasc Diabetol. 2014; 13: 133, doi: 10.1186/ /s12933-014-0133-8, indexed in Pubmed: 25212743.

39. Chen Xi, Lu P, He W, et al. Circulating betatrophin levels are increased in patients with type 2 diabetes and associated with insulin resistance. J Clin Endocrinol Metab. 2015; 100(1): E96-E100, doi: 10.1210/jc.2014-2300, indexed in Pubmed: 25303484.

40. Zhang R. The ANGPTL3-4-8 model, a molecular mechanism for triglyceride trafficking. Open Biol. 2016; 6(4): 150272, doi: 10.1098/rsob.150272, indexed in Pubmed: 27053679.

41. Wawrusiewicz-Kurylonek N, Telejko B, Kuzmicki M, et al. Increased Maternal and Cord Blood Betatrophin in Gestational Diabetes. PLoS One. 2015; 10(6): e0131171, doi: 10.1371/journal. pone.0131171, indexed in Pubmed: 26115519.

42. Abu-Farha M, Abubaker J, Noronha F, et al. Higher plasma betatrophin/ANGPTL8 level in type 2 diabetes subjects does not correlate with blood glucose or insulin resistance. Sci Rep. 2015; 5: 10949, doi: 10.1038/srep10949, indexed in Pubmed: 26077345.

43. Ebert T, Kralisch S, Wurst U, et al. Betatrophin levels are increased in women with gestational diabetes mellitus compared to healthy pregnant controls. Eur J Endocrinol. 2015; 173(1): 1-7, doi: 10.1530/EJE-14-0815, indexed in Pubmed: 25850828.

44. Espes D, Martinell M, Carlsson PO. Increased circulating betatrophin concentrations in patients with type 2 diabetes. Int J Endocrinol. 2014; 2014: 323407, doi: 10.1155/2014/323407, indexed in Pubmed: 24963292.

45. Fu Z, Berhane F, Fite A, et al. Elevated circulating lipasin/betatrophin in human type 2 diabetes and obesity. Scientific Reports. 2014; 4(1), doi: 10.1038/srep05013.

46. Hu H, Sun W, Yu S, et al. Increased circulating levels of betatrophin in newly diagnosed type 2 diabetic patients. Diabetes Care. 2014; 37(10): 2718-2722, doi: 10.2337/dc14-0602, indexed in Pubmed: 25024395.

47. Zielińska A, Maciulewski R, Siewko K, et al. Levels of betatrophin decrease during pregnancy despite increased insulin resistance, beta-cell function and triglyceride levels. Diabetes Metab. 2016; 42(6): 409-415, doi: 10.1016/j.diabet.2016.07.029, indexed in Pubmed: 27555469

48. Li Yy, Xiao R, Li Cp, et al. Increased plasma levels of FABP4 and PTEN is associated with more severe insulin resistance in women with gestational diabetes mellitus. Med Sci Monit. 2015; 21: 426-431, doi: 10.12659/MSM.892431, indexed in Pubmed: 25659997.

49. Zhang $\mathrm{Y}$, Zhang HH, Lu JH, et al. Changes in serum adipocyte fatty acid-binding protein in women with gestational diabetes mellitus and normal pregnant women during mid- and late pregnancy. J Diabetes Investig. 2016; 7(5): 797-804, doi: 10.1111/jdi.12484, indexed in Pubmed: 27181269.

50. Ning $H$, Tao $H$, Weng $Z$, et al. Plasma fatty acid-binding protein 4 (FABP4) as a novel biomarker to predict gestational diabetes mellitus. Acta Diabetol. 2016; 53(6): 891-898, doi: 10.1007/ /s00592-016-0867-8, indexed in Pubmed: 27147422.

51. Tu WJ, Guo M, Shi XD, et al. First-Trimester Serum Fatty AcidBinding Protein 4 and Subsequent Gestational Diabetes Mellitus. Obstet Gynecol. 2017; 130(5): 1011-1016, doi: 10.1097/ /AOG.0000000000002310, indexed in Pubmed: 29016489.

52. Wang D, Zhu W, Li J, et al. Serum concentrations of fibroblast growth factors 19 and 21 in women with gestational diabetes mellitus: association with insulin resistance, adiponectin, and polycystic ovary syndrome history. PLoS One. 2013; 8(11): e81190, doi: 10.1371/journal.pone.0081190, indexed in Pubmed: 24260557.

53. Stein S, Stepan H, Kratzsch J, et al. Serum fibroblast growth factor 21 levels in gestational diabetes mellitus in relation to insulin resistance and dyslipidemia. Metabolism. 2010; 59(1): 33-37, doi: 10.1016/j.metabol.2009.07.003, indexed in Pubmed: 19699495.

54. Dekker Nitert M, Barrett HL, Kubala MH, et al. Increased placental expression of fibroblast growth factor 21 in gestational diabetes mellitus. J Clin Endocrinol Metab. 2014; 99(4): E591-E598, doi: 10.1210/jc.2013-2581, indexed in Pubmed: 24432989.

55. Megia A, Gil-Lluis $\mathrm{P}$, Näf $\mathrm{S}$, et al. Cord blood FGF21 in gestational diabetes and its relationship with postnatal growth. Acta Diabetol. 2015; 52(4): 693-700, doi: 10.1007/s00592-014-0705-9, indexed in Pubmed: 25604041.

56. Abetew DF, Qiu C, Fida NG, et al. Association of retinol binding protein 4 with risk of gestational diabetes. Diabetes Res Clin Pract. 2013; 99(1): 48-53, doi: 10.1016/j.diabres.2012.10.023, indexed in Pubmed: 23153527.

57. Zhaoxia L, Mengkai Du, Qin F, et al. Significance of RBP4 in patients with gestational diabetes mellitus: a case-control study of Han Chinese women. Gynecol Endocrinol. 2014; 30(2): 161-164, doi: 10.3109/09513590.2013.871515, indexed in Pubmed: 24397358.

58. Chan TF, Chen HS, Chen YC, et al. Increased serum retinolbinding protein 4 concentrations in women with gestational diabetes mellitus. Reprod Sci. 2007; 14(2): 169-174, doi: 10.1177/1933719106298407, indexed in Pubmed: 17636228.

59. Krzyzanowska K, Zemany L, Krugluger W, et al. Serum concentrations of retinol-binding protein 4 in women with and without gestational diabetes. Diabetologia. 2008; 51(7): 1115-1122, doi: 10.1007/s00125-008-1009-9, indexed in Pubmed: 18437353.

60. Choi SH, Kwak SH, Youn BS, et al. High plasma retinol binding protein- 4 and low plasma adiponectin concentrations are associated with severity of glucose intolerance in women with previous gestational diabetes mellitus. J Clin Endocrinol Metab. 2008; 93(8): 3142-3148, doi: 10.1210/jc.2007-1755, indexed in Pubmed: 18492757.

61. Maghbooli Z, Hossein-Nezhad A, Mirzaei K, et al. Association between retinol-binding protein 4 concentrations and gestational diabetes mellitus and risk of developing metabolic syndrome after pregnancy. Reprod Sci. 2010; 17(2): 196-201, doi: 10.1177/1933719109351097, indexed in Pubmed: 19897788.

62. Klein K, Bancher-Todesca D, Leipold H, et al. Retinol-binding protein 4 in patients with gestational diabetes mellitus. J Womens Health (Larchmt). 2010; 19(3): 517-521, doi: 10.1089/ /jwh.2009.1615, indexed in Pubmed: 20156079.

63. Su YX, Hong J, Yan Q, et al. Increased serum retinol-binding protein-4 levels in pregnant women with and without gestational diabetes mellitus. Diabetes Metab. 2010; $36(6 \mathrm{Pt} 1$ ): 470-475, doi: 10.1016/j.diabet.2010.06.006, indexed in Pubmed: 21109476.

64. Khovidhunkit W, Pruksakorn P, Plengpanich W, et al. Retinolbinding protein 4 is not associated with insulin resistance in pregnancy. Metabolism. 2012; 61(1): 65-69, doi: 10.1016/j. metabol.2011.05.019, indexed in Pubmed: 21741059.

65. Hu S, Liu Q, Huang X, et al. Serum level and polymorphisms of retinol-binding protein- 4 and risk for gestational diabetes mellitus: a meta-analysis. BMC Pregnancy Childbirth. 2016; 16: 1-11, doi: 10.1186/s12884-016-0838-7, indexed in Pubmed: 26975349.

66. Huang QT, Huang Q, Luo W, et al. Circulating retinol-binding protein 4 levels in gestational diabetes mellitus: a meta-analysis of observational studies. Gynecol Endocrinol. 2015; 31(5): 337-344, doi: 10.3109/09513590.2015.1005594, indexed in Pubmed: 25703255.

67. Abell SK, Shorakae S, Harrison CL, et al. The association between dysregulated adipocytokines in early pregnancy and development of gestational diabetes. Diabetes Metab Res Rev. 2017; 33(8): e2926, doi: 10.1002/dmrr.2926, indexed in Pubmed: 28806491.

68. Lis I, Pilarski $\measuredangle$, Bogdański P. Omentin - a newly-discovered adipocytokine in insulin resistance pathogenesis. Pol Merkur Lekarski. 2015; 39(229): 56-60, indexed in Pubmed: 26277181. 
69. Aktas G, Alcelik A, Ozlu T, et al. Association between omentin levels and insulin resistance in pregnancy. Exp Clin Endocrinol Diabetes. 2014; 122(3): 163-166, doi: 10.1055/s-0034-1370917, indexed in Pubmed: 24643693.

70. Abell SK, De Courten B, Boyle JA, et al. Inflammatory and Other Biomarkers: Role in Pathophysiology and Prediction of Gestational Diabetes Mellitus. Int J Mol Sci. 2015; 16(6): 13442-13473, doi: 10.3390/ijms160613442, indexed in Pubmed: 26110385.

71. Barker G, Lim R, Georgiou HM, et al. Omentin-1 is decreased in maternal plasma, placenta and adipose tissue of women with pre-existing obesity. PLoS One. 2012; 7(8): e42943, doi: 10.1371/ /journal.pone.0042943, indexed in Pubmed: 22952622.

72. Franz M, Polterauer M, Springer S, et al. Maternal and neonatal omentin-1 levels in gestational diabetes. Arch Gynecol Obstet. 2018; 297(4): 885-889, doi: 10.1007/s00404-018-4652-5, indexed in Pubmed: 29335783.

73. Görkem Ü, Küçükler FK, Toğrul C, et al. Are adipokines associated with gestational diabetes mellitus? J Turk Ger Gynecol Assoc. 2016; 17(4): 186-190, doi: 10.5152/jtgga.2016.16112, indexed in Pubmed: 27990086.

74. van Poppel MNM, Zeck W, Ulrich D, et al. Cord blood chemerin: differential effects of gestational diabetes mellitus and maternal obesity. Clin Endocrinol (Oxf). 2014; 80(1): 65-72, doi: 10.1111/ /cen.12140, indexed in Pubmed: 23286837.

75. Hare KJ, Bonde L, Svare JA, et al. Decreased plasma chemerin levels in women with gestational diabetes mellitus. Diabet Med. 2014; 31(8): 936-940, doi: 10.1111/dme.12436, indexed in Pubmed: 24628007

76. Zhang J, $\mathrm{Chi} \mathrm{H}$, Xiao H, et al. Interleukin 6 (IL-6) and Tumor Necrosis Factor $\alpha$ (TNF- $\alpha$ ) Single Nucleotide Polymorphisms (SNPs), Inflammation and Metabolism in Gestational Diabetes Mellitus in Inner Mongolia. Med Sci Monit. 2017; 23: 4149-4157, doi: 10.12659/ /msm.903565, indexed in Pubmed: 28846666.

77. Li XM, Ji H, Li CJ, et al. Chemerin expression in Chinese pregnant women with and without gestational diabetes mellitus. Ann Endocrinol (Paris). 2015; 76(1): 19-24, doi: 10.1016/j. ando.2014.10.001, indexed in Pubmed: 25627894.

78. Yang $X$, Quan $X$, Lan $Y$, et al. Serum chemerin level during the first trimester of pregnancy and the risk of gestational diabetes mellitus. Gynecol Endocrinol. 2017; 33(10): 770-773, doi: 10.1080/09513590.2017.1320382, indexed in Pubmed: 28454507.

79. Pfau D, Stepan H, Kratzsch J, et al. Circulating levels of the adipokine chemerin in gestational diabetes mellitus. Horm Res Paediatr. 2010; 74(1): 56-61, doi: 10.1159/000282114, indexed in Pubmed: 20424419.

80. Fatima SS, Alam F, Chaudhry B, et al. Elevated levels of chemerin, leptin, and interleukin-18 in gestational diabetes mellitus. J Matern Fetal Neonatal Med. 2017; 30(9): 1023-1028, doi: 10.1080/14767058.2016.1199671, indexed in Pubmed: 27278709.

81. Liang Z, Zhou M, Xu XK, et al. Is Chemerin associated with gestational diabetes mellitus? An evidence-based clinical research from Chinese women. J Obstet Gynaecol. 2018; 38(4): 482-487, doi: 10.1080/01443615.2017.1385596, indexed in Pubmed: 29430984.

82. Iyidir OT, Degertekin CK, Yilmaz BA, et al. Serum levels of fetuin A are increased in women with gestational diabetes mellitus. Arch Gynecol Obstet. 2015; 291(4): 933-937, doi: 10.1007/s00404014-3490-3, indexed in Pubmed: 25260988.

83. Kralisch S, Hoffmann A, Lössner $U$, et al. Regulation of the novel adipokines/hepatokines fetuin $A$ and fetuin $B$ in gestational diabetes mellitus. Metabolism. 2017; 68: 88-94, doi: 10.1016/j. metabol.2016.11.017, indexed in Pubmed: 28183456.
84. Gu Y, Li H, Bao X, et al. The relationship between thyroid function and the prevalence of type 2 diabetes mellitus in euthyroid subjects. J Clin Endocrinol Metab. 2017; 102(2): 434-442, doi: 10.1210/jc.2016-2965, indexed in Pubmed: 27906594.

85. Yang S, Shi FT, Leung PCK, et al. Low Thyroid Hormone in Early Pregnancy Is Associated With an Increased Risk of Gestational Diabetes Mellitus. J Clin Endocrinol Metab. 2016; 101(11): 4237-4243, doi: 10.1210/jc.2016-1506, indexed in Pubmed: 27583471.

86. Maleki N, Tavosi Z. Evaluation of thyroid dysfunction and autoimmunity in gestational diabetes mellitus and its relationship with postpartum thyroiditis. Diabet Med. 2015; 32(2): 206-212, doi: 10.1111/dme.12580, indexed in Pubmed: 25186500.

87. Baeyens $\mathrm{L}$, Hindi $\mathrm{S}$, Sorenson $\mathrm{RL}$, et al. $\beta$-cell adaptation in pregnancy. Diabetes Obes Metab. 2016; 18(Suppl 1): 63-70, doi: 10.1111/dom.12716, indexed in Pubmed: 27615133.

88. Parsons JA, Brelje TC, Sorenson RL. Adaptation of islets of Langerhans to pregnancy: increased islet cell proliferation and insulin secretion correlates with the onset of placental lactogen secretion. Endocrinology. 1992; 130(3): 1459-1466, doi: 10.1210/ /endo.130.3.1537300, indexed in Pubmed: 1537300.

89. Scaglia L, Smith FE, Bonner-Weir S. Apoptosis contributes to the involution of beta cell mass in the post partum rat pancreas. Endocrinology. 1995; 136(12): 5461-5468, doi: 10.1210/ /endo.136.12.7588296, indexed in Pubmed: 7588296.

90. Karnik SK, Chen H, McLean GW, et al. Menin controls growth of pancreatic beta-cells in pregnant mice and promotes gestational diabetes mellitus. Science. 2007; 318(5851): 806-809, doi: 10.1126/science.1146812, indexed in Pubmed: 17975067.

91. Van Assche FA, Aerts L, De Prins F. A morphological study of the endocrine pancreas in human pregnancy. $\mathrm{Br} J$ Obstet Gynaecol. 1978; 85(11): 818-820, doi: 10.1111/j.1471-0528.1978. tb15835.x, indexed in Pubmed: 363135.

92. Butler AE, Cao-Minh L, Galasso R, et al. Adaptive changes in pancreatic beta cell fractional area and beta cell turnover in human pregnancy. Diabetologia. 2010; 53(10): 2167-2176, doi: 10.1007/ /s00125-010-1809-6, indexed in Pubmed: 20523966.

93. Huang $C$, Snider F, Cross JC. Prolactin receptor is required for normal glucose homeostasis and modulation of beta-cell mass during pregnancy. Endocrinology. 2009; 150(4): 1618-1626, doi: 10.1210/en.2008-1003, indexed in Pubmed: 19036882.

94. Goyvaerts L, Lemaire K, Arijs I, et al. Prolactin receptors and placental lactogen drive male mouse pancreatic islets to pregnancyrelated mRNA changes. PLoS One. 2015; 10(3): e0121868, doi: 10.1371/journal.pone.0121868, indexed in Pubmed: 25816302.

95. Kim H, Toyofuku Y, Lynn FC, et al. Serotonin regulates pancreatic beta cell mass during pregnancy. Nat Med. 2010; 16(7): 804-808, doi: 10.1038/nm.2173, indexed in Pubmed: 20581837.

96. Ohara-Imaizumi M, Kim H, Yoshida M, et al. Serotonin regulates glucose-stimulated insulin secretion from pancreatic $\beta$ cells during pregnancy. Proc Natl Acad Sci U S A. 2013; 110(48): 19420-19425, doi: 10.1073/pnas.1310953110, indexed in Pubmed: 24218571.

97. Berger M, Scheel DW, Macias $H$, et al. G $\alpha \mathrm{i} / \mathrm{o}$-coupled receptor signaling restricts pancreatic $\beta$-cell expansion. Proc Natl Acad Sci U S A. 2015; 112(9): 2888-2893, doi: 10.1073/pnas.1319378112, indexed in Pubmed: 25695968.

98. Brelje TC, Scharp DW, Lacy PE, et al. Effect of homologous placental lactogens, prolactins, and growth hormones on islet B-cell division and insulin secretion in rat, mouse, and human islets: implication for placental lactogen regulation of islet function during pregnancy. Endocrinology. 1993; 132(2): 879-887, doi: 10.1210/endo.132.2.8425500, indexed in Pubmed: 8425500. 